\title{
Heteronyms in Zhangzhou: Pronunciations and Patterns
}

\author{
Yishan Huang \\ Linguistics Department, Australian National University, Canberra, Australia \\ Email: yishan9898@gmail.com
}

How to cite this paper: Huang, Y. S. (2019). Heteronyms in Zhangzhou: Pronunciations and Patterns. Open Journal of Modern Linguistics, 9, 365-381.

https://doi.org/10.4236/ojml.2019.95030

Received: September 11, 2019

Accepted: October 21, 2019

Published: October 24, 2019

Copyright $\odot 2019$ by author(s) and Scientific Research Publishing Inc. This work is licensed under the Creative Commons Attribution International License (CC BY 4.0).

http://creativecommons.org/licenses/by/4.0/

(c) (i) Open Access

\begin{abstract}
Various criteria can be applied to classify Zhangzhou heteronyms into different categories at different layers, which include the distinction of grammatical categories and lexical meanings, the usage of a colloquial style versus a literary one, the usage of a general style versus a specific one, the phonemic correspondence between the literary and colloquial forms, as well as the number of pronunciations that polyphonetic characters have. Additionally, some patterns can also be generalised with respect to the relationship between different pronunciation forms across diphonetic, triphonetic, quadriphonetic, and quintophonetic characters. The results suggest that although heteronyms are abundant in Zhangzhou, they are essentially arranged in a systematic and generalisable way in the mental grammar of native speakers. This not only reflects a dynamic linguistic phenomenon of heteronyms in this Sinitic dialect, but also indicates the heterogeneous nature of human languages. The study has sought to expand our understanding of the arrangement of heteronyms in the Southern Min variety of Zhangzhou, and serve as a model to investigate how heteronyms are constructed in other Sinitic languages/dialects and beyond.
\end{abstract}

\section{Keywords}

Heteronyms, Polyphonetic Characters, Zhangzhou, Pronunciations, Patterns

\section{Introduction}

Heteronyms, as a linguistic phenomenon, generally refer to those words that are spelt identically but have more than one pronunciation and meaning (Martin et al., 1981; Bergeron, 1990). An example of a common heteronym in English is tear, which when pronounced as /ter/, denotes pulling or ripping something apart or to pieces with force; but, when pronounced as /tir/, denotes a drop of 
liquid secreted from glands in a person's eye. The related words are also referred to as homographs in the literature (Rothwell, 2007; Cramer, 1970; Huang, 2019). As well as this, there exists another type of words, referred to as polyphones, which have more than one pronunciation, but their meanings are associated (Martin et al., 1981; Huang, 2019). This can be illustrated by the word the, which can be pronounced as either /ðə/ or / $/ \mathrm{i} /$, depending on whether its following segment is a consonant or a vowel, and each of these pronunciations has the same meaning.

In the system of Sinitic languages, the vast majority of morphemes are monosyllabic and capable of being represented by a single character (known as Hanzi 汉字) in the written system, though disyllabic or multisyllabic morphemes are also found, for example, pi35.pa22 (“枇杷 loquat”) and pu35.tao22 (“葡萄 grape"). Characters and syllables of sound are thus regarded as having a one-to-one correspondence, and the documentation of Sinitic languages/dialects is conventionally written in terms of characters rather than in IPA symbols. Additionally, being constrained by the limited number of characters, heteronyms that at a broader sense include homographs and polyphones are abundant in Sinitic languages. For example, Liu \& Louise (2009) observed that $73 \%$ of 774 unique heteronyms come from those commonly-used characters. Sung (1973) described two phonological systems as literary and colloquial in the Amoy Chinese dialect. Huang (2019) constructed an inventory of about 900 characters in the Southern Min variety of Zhangzhou, consisting of 793 diphonetic characters, 89 triphonetic characters, 14 quadriphonetic characters, and 4 quintophonetic characters.

This study provides an overview of how the heteronym system is constructed, in particular how different pronunciation forms are related, in a Sinitic dialect of Zhangzhou, which is a prefecture-level city situated in southern Fujian province in South-eastern Mainland China with a total registered population of about 5.1 million. The colloquial language spoken by the majority of native Zhangzhou speakers is Southern Min, also known as Hokkien, which is mutually intelligible with other Southern Min varieties in Fujian and Taiwan, but is completely unintelligible with other Sinitic dialects (e.g., Mandarin, Hakka, Wu, and Cantonese). Heteronyms are particularly abundant in this dialect. For example, as illustrated in Table 1, its numerical system from one to ten, except the number seven, appears to have two different pronunciations, with one occurring in the literary context and another in the colloquial context.

This study, which is built on the corpus of heteronyms presented in Huang's (2019) study, is intended to show how heteronyms are arranged with respect to

Table 1. Different pronunciations of the numerical system in Zhangzhou.

\begin{tabular}{|c|c|c|c|c|c|c|c|c|c|c|}
\hline Style & $\begin{array}{c}\text { 一 } \\
\text { "one" }\end{array}$ & “" & $\begin{array}{c}\text { 三 } \\
\text { "three" }\end{array}$ & $\begin{array}{c}\text { 四 } \\
\text { “four” }\end{array}$ & $\begin{array}{c}\text { 五 } \\
\text { "five" }\end{array}$ & $\begin{array}{c}\text { 六 } \\
\text { "six" }\end{array}$ & $\begin{array}{c}\text { 七 } \\
\text { "seven" }\end{array}$ & $\begin{array}{c}八 \\
\text { “eight” }\end{array}$ & $\begin{array}{c}\text { 九 } \\
\text { "nine" }\end{array}$ & $\begin{array}{c}\text { 十 } \\
\text { "ten" }\end{array}$ \\
\hline Colloquial & tsit221 & 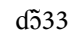 & 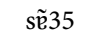 & si41 & gొ33 & dek 221 & $\mathrm{ts}^{\mathrm{h}} \mathrm{it} 41$ & pe 41 & kew51 & tsep221 \\
\hline Literary & Pik41 & zi33 & sem35 & su 41 & ఏว̃51 & djok221 & $\mathrm{ts}^{\mathrm{h}} \mathrm{it} 41$ & pet41 & kju51 & $\operatorname{sip} 221$ \\
\hline
\end{tabular}


different criteria and how different pronunciations are related across polyphonetic characters in Zhangzhou. It is hoped to shape our understanding of the nature of heteronyms in this dialect and also shed light on the investigation of heteronyms in other Sinitic languages/dialects and beyond.

The heteronyms discussed in this study incorporate two types including 1) heteronyms at a narrow sense, involving those homographs that share identical characters but differ in both pronunciations and meanings; and 2) heterophones, involving those heteronyms that have different pronunciations but share the same characters and meanings. The transcriptions of both segments and suprasegments are kept consistent with those formulated in Huang's $(2018,2019)$ studies. Segments were transcribed using IPA 2005 symbols. The tonal pitch was described using Chao's (1930) notational system with 1 representing the lowest level and 5 the highest of an individuals' pitch range. When required, the number 6 was applied to denote the tone having an extra-high pitch level in the non-utterance final context.

This paper is arranged as follows. It will first describe how the Zhangzhou heteronyms can be classified into different categories in terms of various criteria. Next, it will discuss how various forms of pronunciations are related across diphonetic characters, triphonetic characters, quintphonetic characters, and quadriphonetic characters. Finally, it will also provide a conclusion with respect to the descriptions in this study.

\section{Classification of Heteronyms}

The heteronyms of Zhangzhou can be classified into different categories in terms of various criteria. To be more specific, they can be classified on the basis of the linguistic function of different pronunciations. As well as this, they can be classified into seven different patterns with respect to the correspondence pattern of syllable onset, final and tone between different pronunciations. The term final specifically refers to the syllable components that exclude onset in traditional Chinese phonology (e.g., Zhang \& Yang, 2009; Huang, 2019). An additional aspect is that the heteronyms can also be categorised into diphonetic, triphonetic, quintphonetic, and quadriphonetic groups in terms of the number of pronunciations that the related characters have. This section, thus, mainly discusses how the Zhangzhou heteronyms can be arranged, in a broad sense, with respect to different grouping criteria.

The pronunciation differences of the heteronyms in Zhangzhou is mainly to fulfill a particular linguistic function, involving the distinguishment of parts of speech, lexical meanings, as well as different usage styles, such as a colloquial versus a literary usage, and a general versus a special usage. As illustrated in (1) below, the change of pronunciations gives rise to the change in the grammatical category of related characters. For example, the character 种 denotes a verb "to plant" when pronounced as tsin41, but suggests a noun "seed" when articulated as $\operatorname{tsin} 51$. 
(1) Distinguishing different parts of speech

\begin{tabular}{|c|c|c|}
\hline ћjen41 & verb & hjen63.sin35 “to show up 现身” \\
\hline hjen33 & adjective & hjen32.tej33 “current era 现代” \\
\hline $\operatorname{tsin} 41$ & verb & tsin63.ћwe35 “to plant flowers 种花” \\
\hline $\mathrm{t} \sin 51$ & noun & tsin35.tsi51 “seed 种子” \\
\hline $\operatorname{tin} 41$ & verb & tin41.de.k $\mathrm{h}^{\mathrm{h}}$ “to nail down 钉下去” \\
\hline $\operatorname{tin} 35$ & noun & thi63.tin35 “piton 铁钉” \\
\hline den 22 & adjective & tsin32.den 22 “very difficult \\
\hline den33 & noun & tsej33.den33 “disaster 灾难 \\
\hline
\end{tabular}

The different pronunciations of Zhangzhou heteronyms can be used to signify different usage registers of colloquial and literary. Following the traditional Chinese linguistics (e.g., Sung, 1974; Ma, 1994), the colloquial register refers to an informal spoken form used in daily conversations of all classes, while the literary register refers to a formal linguistic form that is mainly used to read the written language; but also used in local news broadcasting, in the citations of literature in lectures, sermons and operas, as well as in addressing people by name. For example, as shown in (2) below, the character 飞 "to fly" is articulated as hwi35 when it is used in a formal context of airplane, but as pwe35 when it is used in an informal conversation. There appears an obvious distinction between the colloquial and literary forms.

(2) Colloquial vs. literary reading

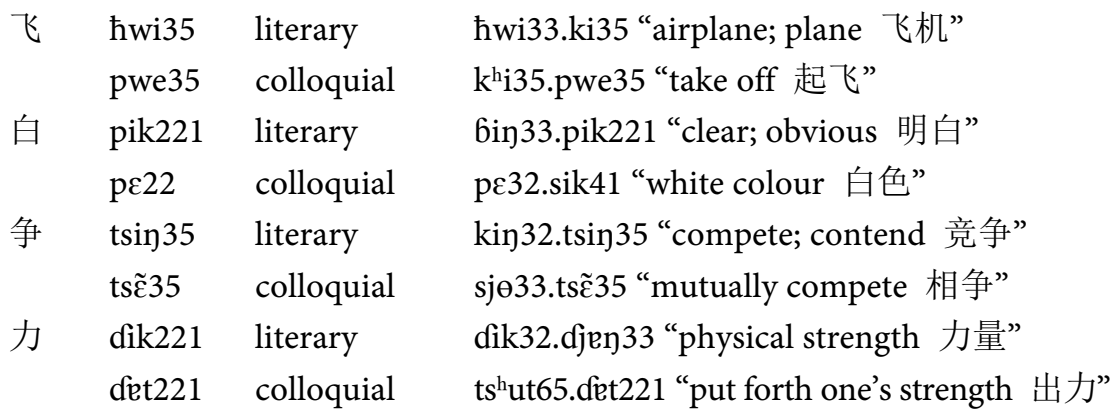

The difference in pronunciation of those heteronyms, known as homographs, is mainly applied to denote different lexical meanings. For example, as illustrated in (3) below, when pronounced as pe22, the character 爬 bears the meaning of "to crawl", whereas the pronunciation of pe41 is mapped into the meaning of "to climb". It is obvious that the two meanings are not the same.

(3) Distinguish different meanings

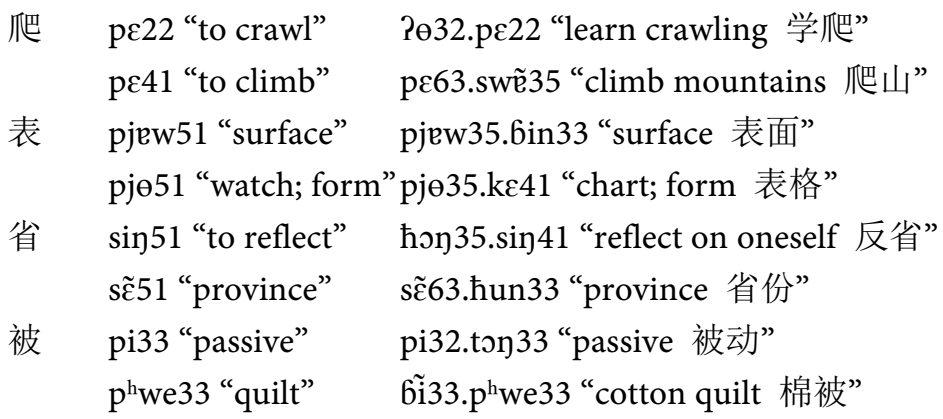

Some pronunciation differences can distinguish whether the corresponding 
heteronyms are used at a general or a special occasion. A good example of this is the diphonetic character 妹, as shown in (4). When pronounced as 6r̃ j35, it denotes an address to any young girl in the Southern Min culture. Alternatively,

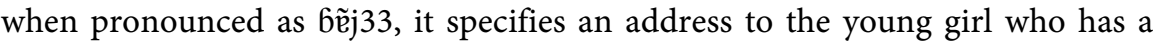
blood relationship with the addressee. As well as this, the character 衣 is used to express "a coat" when in the form of Pi35, but to signify "a placenta" when it is combined with the character 胎 ( $\mathrm{t}^{\mathrm{h}} \mathrm{ej} 33$ "fetus") and articulated as ?wi35.

(4) General vs. special usage

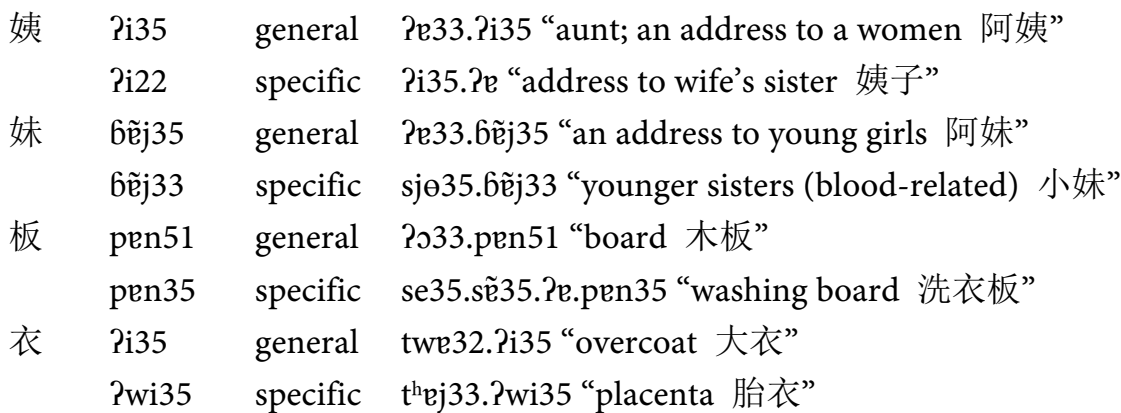

The heteronyms that have literary and colloquial pronunciations can be classified into seven groups in terms of the correspondence between the two different forms in terms of syllable onset, final and tone, which is summarised in (5). As illustrated in (5a), the two pronunciations $t s^{h} u 51$ and $t s^{h} u 41$ for the character 处 share identical syllable onset and final but differ in tone. The pronunciations $\sin 35$ and sje 35 for the character 声 in (5b) differ mainly in final. As well as this, the character - in $(5 \mathrm{~g})$ has two pronunciations Pit41 and tsit22 that differ in syllable onset and tone while have the same final.

(5) Correspondence of syllable onset, final and tone between literary and colloquial forms.

(5a) Same onset and final but different tones

\begin{tabular}{|c|c|}
\hline $\mathrm{ts}^{\mathrm{h}} \mathrm{u} 51$ & tsh u35.di51 “handle 处理” \\
\hline $\mathrm{ts}^{\mathrm{h}} \mathrm{u} 41$ & ts ${ }^{\mathrm{h}} \mathrm{u} 63 . \mathrm{tj} \tilde{0} 51$ “section chief 处长” \\
\hline pwe33 & Pwi33.pwe33 “violate; go against 违背” \\
\hline pwe41 & pwe63.kin51 “background 背景” \\
\hline $\mathrm{t} \sin 41$ & tsin63.ћwe35 “to plant flowers 种花” \\
\hline $\operatorname{tsin} 51$ & tsin35.tsi51 “seed 种子” \\
\hline ћjen41 & ћjen63.sin35 “to show up 现身” \\
\hline hjen33 & ћjen32.tej33 “current era; modern times 现代” \\
\hline
\end{tabular}

(5b) Same onset and tone but different finals

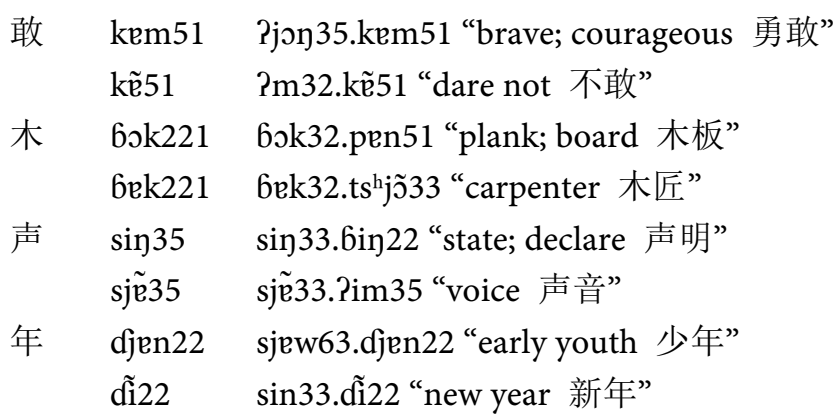


(5c) Same onset but different tones and finals

$\begin{array}{lll}\text { 监 } & \text { kem41 } & \text { kem63.tok41 “supervise 监督” } \\ & k \tilde{e} 35 & \text { kẽ 33.de22 “prison; jail 监牢” } \\ \text { 斗 } & \text { to41 } & \text { to63.tsin35 “fight; combat 斗争” } \\ & \text { tew51 } & \text { pek65.tew51 “Beidou (place) 北斗” } \\ \text { 月 } & \text { gwet221 } & \text { bin33.gwet221 “moon 明月” } \\ & \text { gwe22 } & \text { gwe32.djen33 “moon 月亮” } \\ \text { 有 } & \text { Pju51 } & \text { so35.Pju51 “own; possess 所有” } \\ & \text { Pu33 } & \text { Pu32.tswi51 “have water 有水” }\end{array}$

(5d) Same tone but different onsets and finals

厚 ћo33 tsjon33.ћo33 “sincere and kind 忠厚”

kew33 kew32.de51 “lavish gifts 厚礼”

放 ћon41 kej35.ћon41 “liberate; emancipate 解放”

pen41 pen32.sim35 “be at ease 放心”

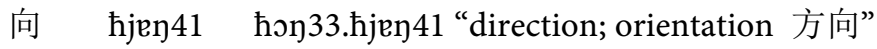

?n41 Pn63.dem 22 "face south 向南”

寒 hen22 trj32.ћen22 "great cold (24th solar term) 大寒”

kwẽ22 kwẽ33.tñ $\tilde{\text { in }}$ “winter 寒天”

(5e) Different onsets, finals, and tones

学 ћek221 ћøk65.sip221 “study; learn 学习”

Pө22 Pө32.tn22 “school 学堂”

多 te35 te33.sjew51 “more or less 多少”

tse33 tsin32.tse33 “too many; too much 真多”

叶 Pjep221 sг̃63.Pjep221 “Ye (surname)姓叶”

$\hbar j e 22$ ts ${ }^{\mathrm{h} j u}$ 32.ћje35.?e “leaf 树叶”

远 Pwen51 Pwen35.hin22 “go on a long journey 远行”

ћwi33 ћwi32.d033 “long journey 远路”

(5f) Same final and tone but different onsets

谢 sje33 kem35.sje33 “be grateful 感谢”

tsje33 s 6 63.tsje33 “Xie (surname) 姓谢”

支 tsi35 tsi33.tshi22 “support 支持”

ki35 tsit32.ki33.pit41 “one pen 一支笔”

斧 hu51 hu35.tsjẽ 41 “make corrections 斧正”

$\mathrm{p}^{\mathrm{h}} \mathrm{u} 51 \quad \mathrm{p}^{\mathrm{h}} \mathrm{u} 35 . \mathrm{t}^{\mathrm{h}} \mathrm{ew} 22$ “axe 斧头”

胡 $\hbar 022$ ћo33.swet41 “non-sense talk 胡说”

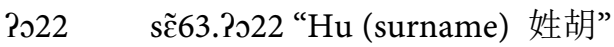

(5g) Same final but different onsets and tones

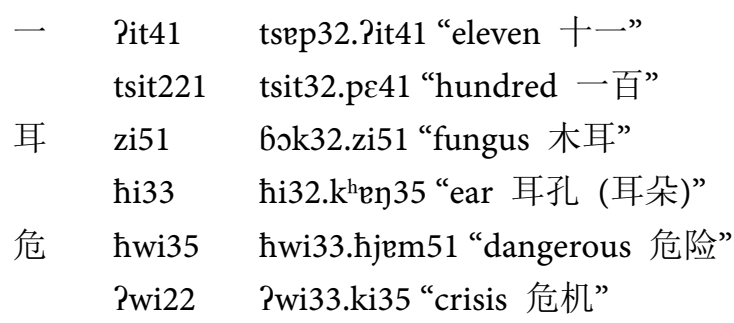




\section{率 sut41 then35.sut41 "frank; straightforward 坦率” \\ dut221 ћew32.dut221 “efficiency 效率”}

The heteronym inventory in this dialect can also be classified into four different categories in terms of the number of pronunciations, which include diphonetic, triphonetic, quadriphonetic, and quintphonetic; but the overwhelming majority are diphonetic (Huang, 2019). More specifically, as illustrated in (6) below, the character 下 in (6a) has two different pronunciations $\hbar \varepsilon 33$ and $2 \varepsilon 33$. The character 西 in (6b) has three pronunciations se35, ssj35 and si35. Four different pronunciations are discovered for the character 成 in (6c), which are

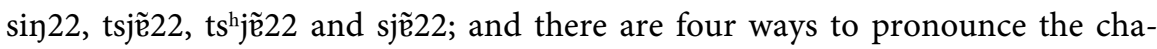
racter 平 in (6d), which are pin22, $\mathrm{p}^{\mathrm{h}} \mathrm{in} 22, \mathrm{p} \tilde{\varepsilon} 22, \mathrm{p}^{\mathrm{h}} \tilde{\varepsilon} 35$ and $\mathrm{p}^{\mathrm{h}} \tilde{\varepsilon} 22$.

(6) Heteronym classification in terms of the number of pronunciations

(6a) Diphonetic characters

\begin{tabular}{|c|c|c|}
\hline 下 & $\hbar \varepsilon 33$ & ћع32.din33 “give orders 下令” \\
\hline & ?ع33 & Pع32.te51 "underneath 下底 (下面)" \\
\hline & pi33 & pi32.ton33 “passive 被动” \\
\hline & $\mathrm{p}^{\mathrm{h}} \mathrm{we} 33$ & 6ĩ33.p ${ }^{\mathrm{h}} w e 33$ “cotton quilt 棉被” \\
\hline & $\operatorname{zin} 22$ & zin33.6in22 “the people 人民” \\
\hline & den 22 & ћө35.den22 “nice people 好人” \\
\hline & Pi51 & 6ok32.Pi51 “torrential rain 暴雨” \\
\hline & ћ०33 & de32.ћ๊33 “to rain 落雨” \\
\hline
\end{tabular}

(6b) Triphonetic characters

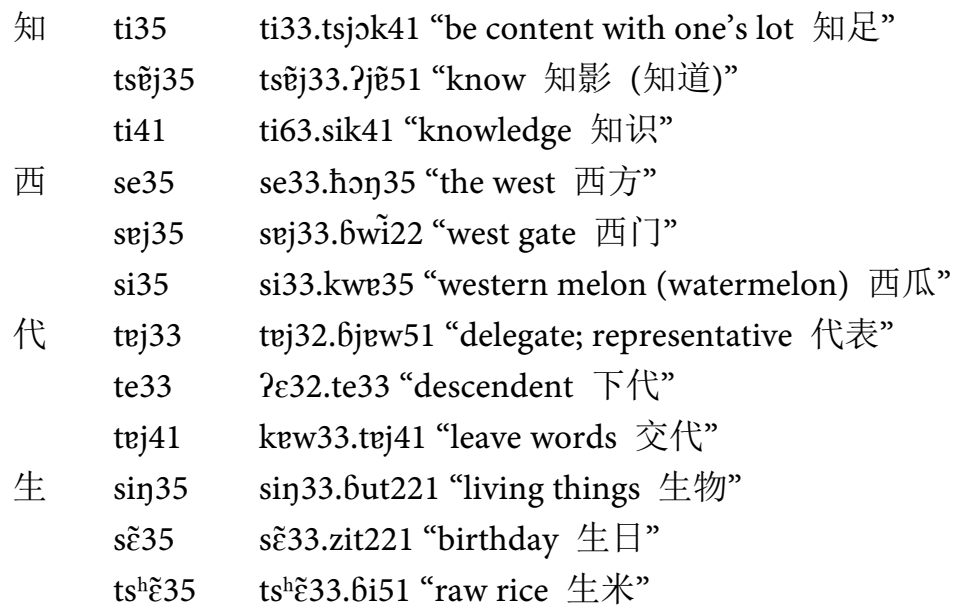

(6c) Quadriphonetic characters

\begin{tabular}{|c|c|}
\hline tjon 35 & tjon33.sim35 “centre; centrum 中心” \\
\hline ten 35 & ts $^{\mathrm{h}}$ en 33.ten33.Pn35 “Tianzhongyang (place) 田中央” \\
\hline tjon 41 & 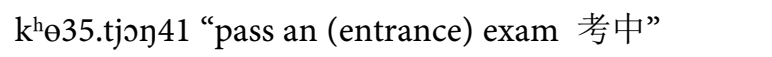 \\
\hline $\operatorname{tin} 41$ & tin63.2i41 “be to one’s liking 中意” \\
\hline $\mathrm{k}^{\mathrm{h}} \mathrm{\jmath} 35$ & kbon33.kun35 “air force 空军” \\
\hline $\mathrm{k}^{\mathrm{h}} \mathrm{en} 35$ & kºn33.tshju51 “empty-handed 空手” \\
\hline $\mathrm{k}^{\mathrm{h}} \mathrm{\jmath} 41$ & tsit32.pe63.k ${ }^{\mathrm{h}} 0$ n63.zi33 “102 一百零二” \\
\hline $\mathrm{k}^{\mathrm{h}} \mathrm{en} 41$ & khen63.te33 “vacant lot 空地” \\
\hline $\sin 22$ & sin33.ke35 “form a family 成家” \\
\hline
\end{tabular}


Table 2. Correspondence patterns of the literary and colloquial onsets of diphonetic characters.

\begin{tabular}{|c|c|c|c|c|c|}
\hline Literary & \multicolumn{5}{|c|}{ Colloquial } \\
\hline 6 & $?$ & & & & \\
\hline d & $\mathrm{t}$ & & & & \\
\hline$\hbar$ & $\mathrm{k}$ & $\mathrm{k}^{\mathrm{h}}$ & $\mathrm{p}$ & $\mathrm{p}^{\mathrm{h}}$ & ? \\
\hline $\mathrm{k}$ & $\mathrm{k}^{\mathrm{h}}$ & & & & \\
\hline $\mathrm{k}^{\mathrm{h}}$ & $\mathrm{k}$ & & & & \\
\hline $\mathrm{p}$ & $\mathrm{p}^{\mathrm{h}}$ & & & & \\
\hline $\mathrm{p}^{\mathrm{h}}$ & $\mathrm{p}$ & & & & \\
\hline s & ts & $\mathrm{ts}^{\mathrm{h}}$ & & & \\
\hline $\mathrm{t}$ & $\mathrm{t}^{\mathrm{h}}$ & ts & & & \\
\hline$t^{\mathrm{h}}$ & $\mathrm{t}$ & $\mathrm{k}$ & & & \\
\hline ts & $\mathrm{k}$ & $\mathrm{t}$ & $\mathrm{ts}^{\mathrm{h}}$ & & \\
\hline $\mathrm{ts}^{\mathrm{h}}$ & $\mathrm{k}^{\mathrm{h}}$ & s & $\mathrm{t}$ & $t^{\text {h }}$ & ts \\
\hline $\mathrm{z}$ & d & $\hbar$ & $?$ & ts & $\mathrm{ts}^{\mathrm{h}}$ \\
\hline
\end{tabular}

Table 3. Correspondence patterns between the literary and colloquial finals among diphonetic characters.

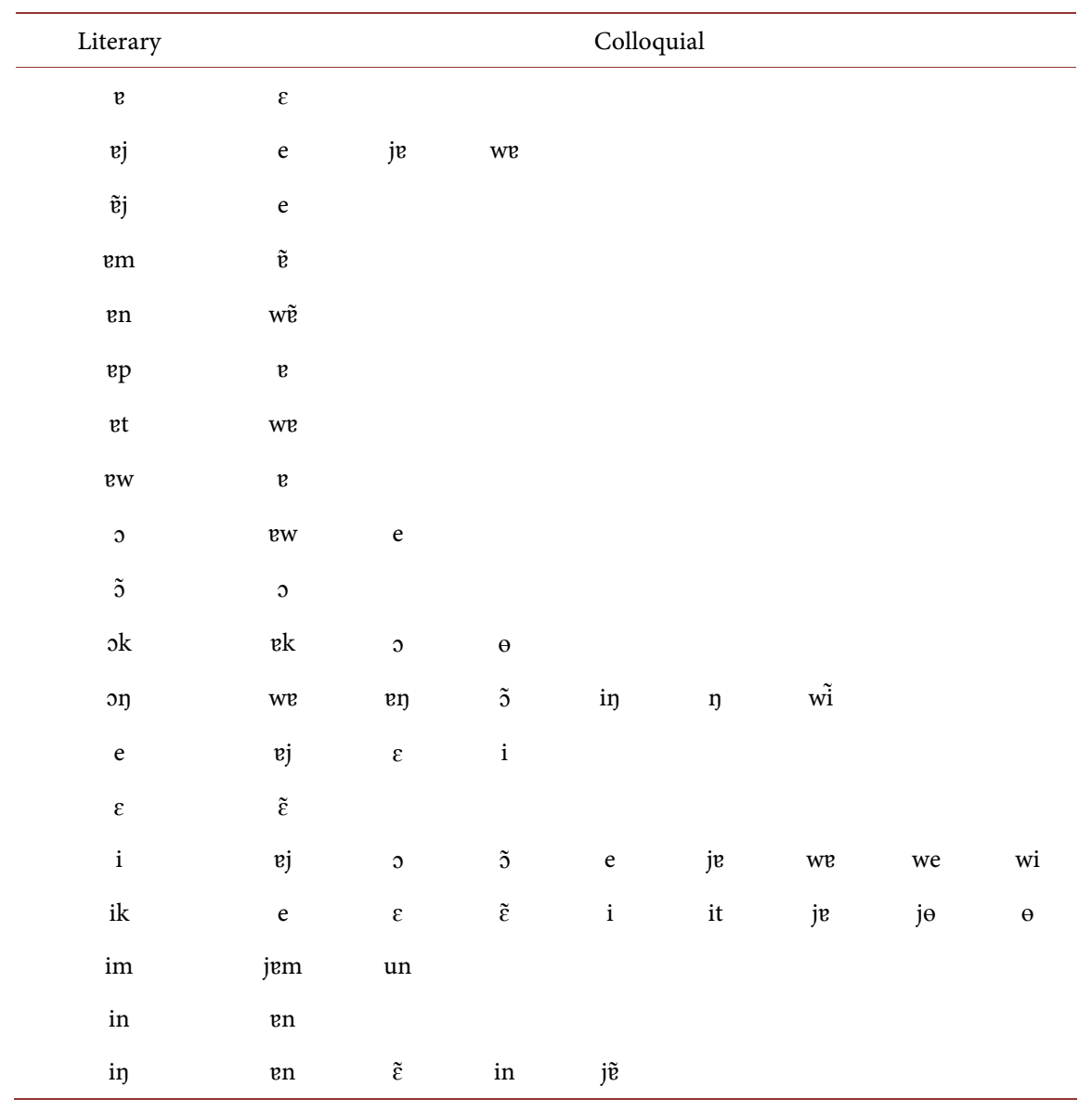




\section{Continued}

\begin{tabular}{|c|c|c|c|c|c|}
\hline ip & ер & & & & \\
\hline it & pt & $\mathrm{i}$ & & & \\
\hline je & $\mathfrak{e}$ & we & & & \\
\hline jek & je & je & & & \\
\hline jem & $\tilde{\mathrm{i}}$ & jen & & & \\
\hline jen & en & $\tilde{\mathrm{i}}$ & in & $j \tilde{\boldsymbol{\varepsilon}}$ & wẽ \\
\hline jen & j̃̃ & $\mathrm{n}$ & & & \\
\hline jep & $\mathcal{E}$ & je & et & & \\
\hline jet & et & $\mathrm{i}$ & & & \\
\hline jew & $\mathfrak{B}$ & $\mathrm{BW}$ & $\mathrm{j} \theta$ & & \\
\hline jok & $\mathrm{ek}$ & $\mathrm{ok}$ & $\mathrm{ik}$ & & \\
\hline jon & on & in & jõ & & \\
\hline $\mathrm{ju}$ & $\mathrm{EW}$ & jũ & $\mathrm{u}$ & & \\
\hline$\theta$ & $\mathrm{EW}$ & 0 & e & we & we \\
\hline $\mathrm{u}$ & ej & 0 & $\mathrm{i}$ & & \\
\hline un & in & wĩ & & & \\
\hline wen & en & $\tilde{\mathrm{i}}$ & un & 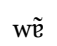 & wĩ \\
\hline wet & we & we & & & \\
\hline wi & we & wi & & & \\
\hline
\end{tabular}

by the following examples in (7a) and (7b). For instance, $/ \mathrm{h} /$ is related to $/ \mathrm{k} /$ for the character 寒 (ћen 22 vs. kwẽ 22 ), to $/ \mathrm{k}^{\mathrm{h}} /$ for the character 呼 (ћo35 vs. $\mathrm{k}^{\mathrm{h}} \mathrm{35}$ ), to $/ \mathrm{p} /$ for the character 飞 (ћwi35 vs. pwe35), to $/ \mathrm{p}^{\mathrm{h}} /$ for the character

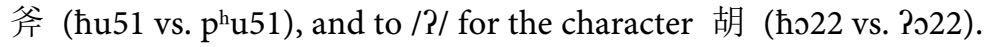

(7) Illustration of onset correspondence pattern of diphonetic characters

(7a) The literary-colloquial correspondence patterns of the $/ \hbar /$ onset /h/-/k/

寒 $\hbar e n 22$ trj32.ћen 22 "great cold (24th solar term) 大寒”

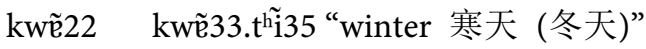

汗 ћen41 ћen63.6e51 “distinctions won in battle 汗马”

kwẽ33 dew33.kwẽ 33 “sweat 流汗”

厚 ћっ33 tjon33.ћo33 “sincere and kind 忠厚”

kew33 kew32.de51 “lavish gifts 厚礼”

$/ \mathrm{h} /-/ \mathrm{k}^{\mathrm{h}} /$

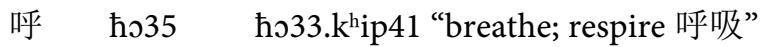

$\mathrm{k}^{\mathrm{h}}$ 035 k $\mathrm{k}^{\mathrm{h}}$ 33.ke35.?e51 “call chicken 呼鸡”

环 ћwen22 ћwen33.kju22 “around the world 环球”

$\mathrm{k}^{\mathrm{h}} \mathrm{wen} 22 \mathrm{k}^{\mathrm{h}} \mathrm{wen} 33 . \mathrm{sj} \tilde{\mathrm{e}} 22$ "around the city 环城”

许 hi51 Pin35.hi51 "permit; allow 允许”

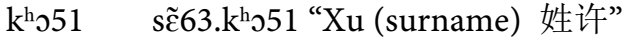




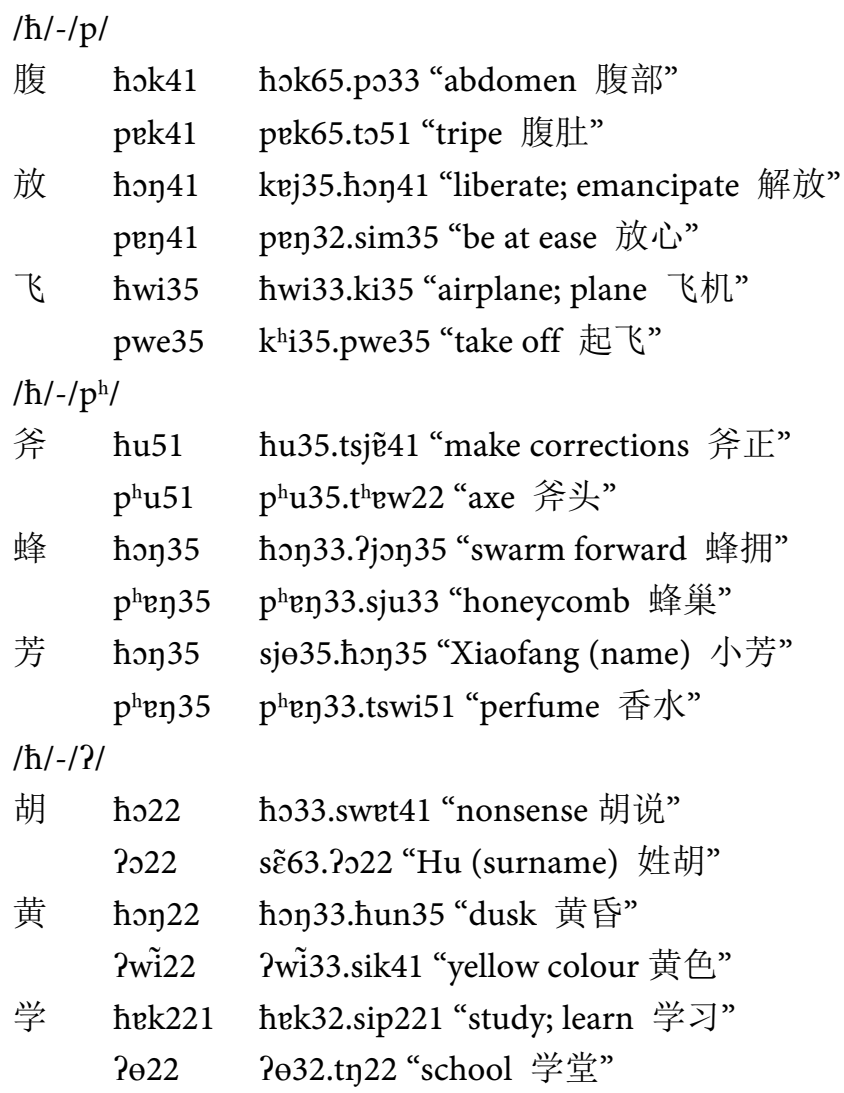

(7b) The literary-colloquial correspondence patterns of the /s/onset /s/-/ts/

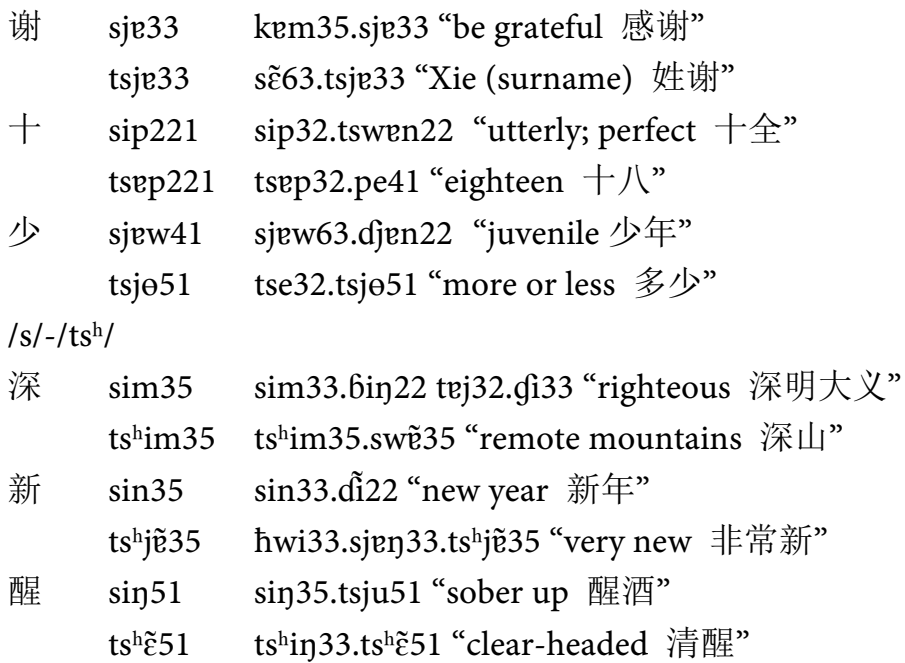

As well as this, the relationships between literary and colloquial finals also form some generalisable patterns as summarised in Table 3 and illustrated in (8). A good example of this is the final / $\mathrm{ej} /$ in (8a), when used in the colloquial setting, it is either correlated to /e/ as for the character 改 (kej51 vs. ke51) or to /we/ as for the character 带 (trj41 vs. twe41). Similarly, the /in/ final in (8b) has three different colloquial counterparts that include / $\tilde{\varepsilon} /$ for the character 省

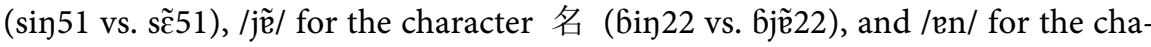
racter 肯 ( $\mathrm{k}^{\mathrm{h}} \mathrm{in} 51$ vs. $\mathrm{k}^{\mathrm{h}} \mathrm{en} 51$ ). The final /en/ in (8c) largely corresponds to /wẽ/ 


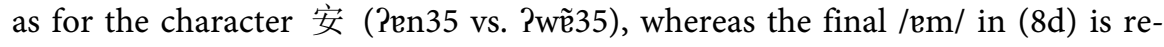
lated to / $\tilde{\mathfrak{e}} /$ when it is used in the colloquial conversation for the character 敢 (kem51 vs. kẽ 51). Thus, although substantial differences exist in the literary and colloquial readings for the diphonetic characters, patterns can be generalised to reflect their relationship. More examples in this aspect can be referred to in Huang's (2019) study.

(8) Illustration of onset correspondence pattern of diphonetic characters

(8a) The literary-colloquial correspondence patterns of the / $\mathrm{pj} /$ final / $\mathrm{ej} /-/ \mathrm{e} /$

改 kej51 kej35.tsin41 “correct; amend 改正” ke51 sju33.ke51 “revise 修改”

灾 tsej35 tsej33.den33 “disaster 灾难”

tse35 tje32.tse35 “get oneself in trouble 着灾”

戒 krj41 krj63.gjem22 “impose a curfew 戒严”

ke51 ke35.tsju51 “abstinence 戒酒”

/ej/-/we/

带 tej41 hrj35.tej41 “kelp; sea tangle 海带”

twe41 twe63.djẽ 51 “guide; lead 带领”

芥 kej41 kej63.dwe22 “mustard 芥辣 (芥末)”

kwe41 kwe63.ts ${ }^{\mathrm{h}} \mathrm{ej} 41$ “mustard leaf 芥菜”

大 trj33 trj32.zin22 “ambassador 大人”

twe33 twe32.2e22 “university 大学”

(8b) The literary-colloquial correspondence patterns of the /in/final /in/-/ $\tilde{\varepsilon} /$

省 $\sin 51$ hon35.sin51 “reflect on oneself 反省”

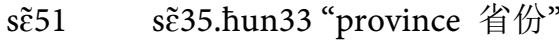

争 $t \sin 35 \mathrm{kin} 32 . t \sin 35$ “compete; contend 竞争”

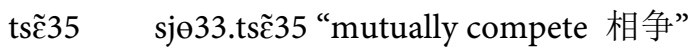

青 tshin35 tshin33.sjon22 “Qingsong (people) 青松”

ts ${ }^{\mathrm{h}} \tilde{\varepsilon} 35$ ts ${ }^{\mathrm{h}} \tilde{\varepsilon} 33 . s i k 41$ “green colour 青色”

/in/-/jẽ /

名 bin22 bin33.6on33 “fame and prestige 名望”

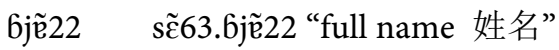

命 $\operatorname{bin} 33$ bin32.din33 “order; command 命令”

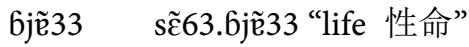

声 $\sin 35 \sin 33.6 i n 22$ “state; declare 声明”

sjês5 sjẽ 33.Pim35 “voice 声音”

/in/-/en/

零 din22 din33.hun35 “no marks 零分”

den22 den33.sen35 “sporadic; piecemeal 零星”

肯 $\mathrm{k}^{\mathrm{h}}$ in51 $\mathrm{k}^{\mathrm{h}}$ in35.tin33 “affirmative 肯定”

$k^{\mathrm{h}} \mathrm{en} 51$ ?m32.k $\mathrm{k}^{\mathrm{h}} \mathrm{en} 51$ “refuse to 不肯”

等 tin51 tin35.kip41 “grade; rank 等级”

ten51 ten35.thej33 “wait 等待” 
(8c) The literary-colloquial correspondence patterns of the /en/final /en/-/wẽ/

\begin{tabular}{|c|c|c|}
\hline 满 & ben51 & 6en35.tshin35 “Qing dynasty 满清” \\
\hline & 6wẽ 51 & 6i35.6wẽ 51 “perfectly satisfactory 美满” \\
\hline & Pen35 & Pen33.tswen22 “secure; safety 安全” \\
\hline & 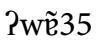 & ten33.Pwẽ 35 “Tong’an (place) 同安” \\
\hline & ћеn 22 & tej32.ћen22 “extremely cold 大寒” \\
\hline & $\mathrm{kw} \tilde{2} 22$ & kwẽ $33 . t$ ti 35 “winter 寒天 (冬天)” \\
\hline
\end{tabular}

(8d) The literary-colloquial correspondence patterns of the $/ \mathrm{em} /$ final

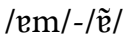

蓝 dem22 dem33.sik41 “blue colour 蓝色”

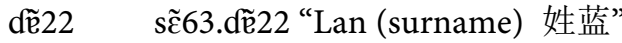

敢 kem51 Pjon35.kem51 “brave; courageous 勇敢”

kẽ51 Pm32.k 51 “dare not 不敢”

监 kem41 kem63.tok41 “supervise 监督”

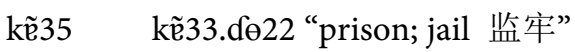

\section{Triphonetic Characters}

The characters that have three different pronunciations can be classified into three groups, including 1) those that have two literary pronunciations and one colloquial pronunciation; 2) those that have two colloquial pronunciations and one literary form; and 3) those that differ only in tone. For example, as illustrated below, the character 订 in (9a) is produced as either tin33 or tin 41 in the literary context but as tjể3 in the colloquial setting. The character 正 in (9b), on the other hand, has one pronunciation tsin 41 in the literary context, but has two pronunciations of tsjẽ 41 and tsjẽ 35 in the colloquial situation. Conversely, the three pronunciations ?wi33, ?wi41, and ?wi22 for the character 为 in (9c) differ only in the variation of tonal pitch.

(9) Illustration of pronunciation correspondence pattern of triphonetic characters

(9a) Triphonetic characters with two differences in the literary context

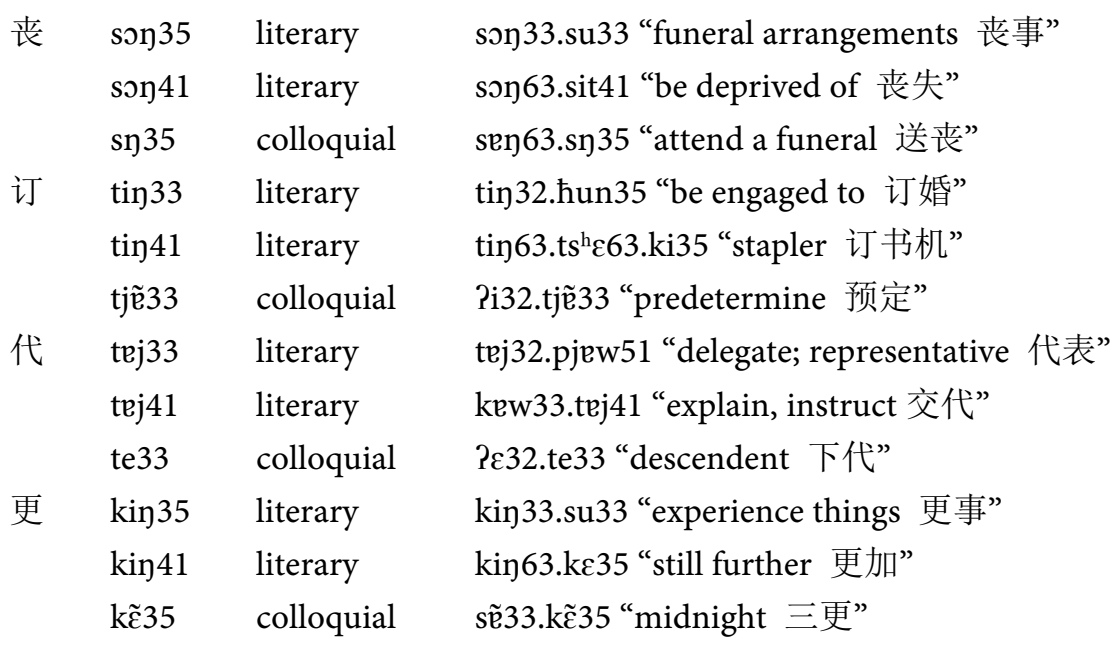


(9b) Triphonetic characters with two differences in the colloquial context

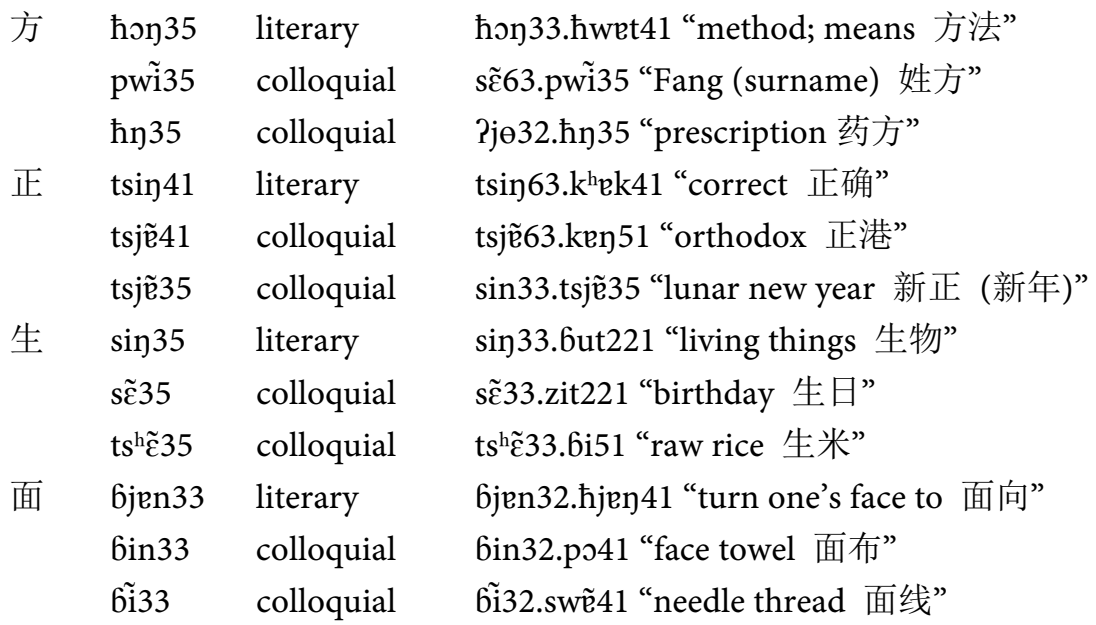

(9c) Triphonetic characters with three differences in tone

为 ?wi33 “for the sake of" Pwi32.he22 “why 为何”

?wi41 "because” Pin33.?wi41 "because 因为”

?wi22 “act” hin33.?wi22 “action; behaviour 行为”

遐 hje51 “those” hje51.?e “those (things) 遐的”

hje35 “there” kn $\mathrm{k}^{\mathrm{h}}$ 63.hje35 “go there 去遐 (去哪儿)”

hje41 “so; in that way” hje63.tse33 “that much 遐多”

\section{Quadriphonetic Characters}

Quadriphonetic characters that have four different pronunciations can be classified into three categories, including 1) those that have two pronunciation differences in both literary and colloquial contexts; 2) those that have three pronunciation differences in the colloquial context but only one pronunciation in the literary context, and 3) those that have pronunciation differences only in the tonal pitch. This can be illustrated by the following examples. For instance, the character 中 in (10a) has two literary pronunciations tjon35 and tjon41; as well as two pronunciations tjon 41 and tin 41 that occur in the colloquial context. The character 成 in (10b) has three colloquial readings tsjẽ $22, t s^{h} j \tilde{e} 22$, and $s j \tilde{\mathbf{e}} 22$ as well as one reading $\sin 22$ used in a formal literary setting. Additionally, the four

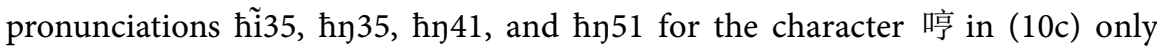
differ obviously in tone.

(10) Illustration of pronunciation correspondence pattern of triphonetic characters

(10a) Quadriphonetic characters with two differences in literary and colloquial contexts

\begin{tabular}{|c|c|c|}
\hline tjon35 & literary & tjon33.sim35 “centre; centrum 中心” \\
\hline tjon 41 & literary & $\mathrm{k}^{\mathrm{h}} \mathrm{\Theta 35.tjon} 41$ “pass an (entrance) exam 考中” \\
\hline & colloquial & $\mathrm{ts}^{\mathrm{h}} \mathrm{en} 33 . \operatorname{ten} 33 . \mathrm{Pn} 35$ “Tianzhongyang 田中央 \\
\hline 41 & colloquial & tin63.Pi41 “be to one’s liking 中意” \\
\hline
\end{tabular}

(10b) Quadriphonetic characters with two differences in literary and colloqui- 
al contexts

\begin{tabular}{|c|c|c|}
\hline tjon35 & literary & tjon33.sim35“centre; centrum 中心” \\
\hline tjon 41 & literary & $\mathrm{k}^{\mathrm{h}} \mathrm{e} 35 . \mathrm{tjoy} 41$ “pass an (entrance) exam 考中” \\
\hline ten35 & colloquial & 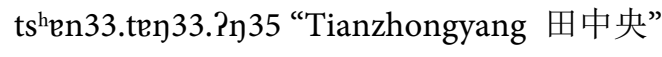 \\
\hline $\operatorname{tin} 41$ & colloquial & tin63.Pi41 “be to one’s liking 中意” \\
\hline ћер41 & literary & ћеp41.dwe “shut up; close 合起来” \\
\hline ћер221 & literary & ћep32.tsok41 “collaborate 合作” \\
\hline ke41 & colloquial & ke63.2i41 “suit one's intension 合意” \\
\hline Pe22 & colloquial & Pe32.su35 “fit body 合身” \\
\hline $\mathrm{k}^{\mathrm{h}} \mathrm{on} 35$ & literary & $k^{\mathrm{h}}$ $033 . k u n 35$ “air force 空军” \\
\hline $\mathrm{k}^{\mathrm{h}}$ э) 41 & literary & tsit32.pe63.k 0 b63.Pit41 “101 一百空一” \\
\hline $\mathrm{k}^{\mathrm{h}} \mathrm{en} 35$ & colloquial & ken33.tshju51 “empty-handed 空手” \\
\hline $\mathrm{k}^{\mathrm{h}} \mathrm{en} 41$ & colloquial & khen63.te33 “vacant lot 空地” \\
\hline $6 e t 221$ & literary & 6et32.6et221 “dense 密密” \\
\hline bit221 & literary & 6it32.ћ๊n35 “seal; seal up 密封” \\
\hline $6 e 33$ & colloquial & 6ө33.6e33 “not closed 无密 (门没关紧)” \\
\hline $6 \varepsilon 22$ & colloquial & 6ع32.6ع22 “dense; numerous 密密” \\
\hline
\end{tabular}

(10c) Quadriphonetic characters with three differences in the colloquial context

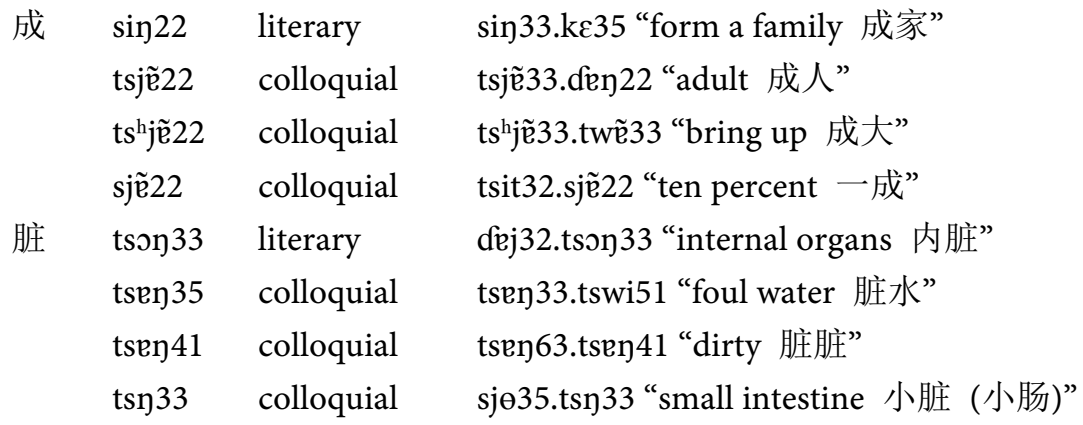

(10d) Quadriphonetic characters with differences in tone

哼 ћî35 “moan"

hy35 "moan; groan; particle showing a question"

ћฤ41 "yes; particle showing consent"

ћ551 "particle showing anger"

\section{Quintophonetic Characters}

Four characters are found to have five different pronunciations with three forms used in the colloquial context and two forms in the literary setting. To illustrate, the character 平 in (11) has two literary pronunciations pin22 and $\mathrm{p}^{\mathrm{h}} \mathrm{in} 22$; as well as three colloquial pronunciations $\mathrm{p} \tilde{\varepsilon} 22, \mathrm{p}^{\mathrm{h}} \tilde{\varepsilon} 35$, and $\mathrm{p}^{\mathrm{h}} \tilde{\varepsilon} 22$. The meanings change considerably among different morphemes. For example, for the character 长, three different meanings can be derived. There are two pronunciations that are assigned with the meaning of "long", in both the literary and the colloquial contexts; and two pronunciations with the meaning of "head; elder". Another sound form is used for the specific geographical name of "Changtai". 
(11) Illustration of pronunciation correspondence pattern of quinphonetic characters

\begin{tabular}{|c|c|c|c|}
\hline \multirow[t]{5}{*}{ 平 } & $\operatorname{pin} 22$ & literary & pin33.tin51 “equality 平等” \\
\hline & $\mathrm{p}^{\mathrm{h}}$ in 22 & literary & $\mathrm{p}^{\mathrm{h}} \mathrm{in} 33 . t \sin 33$ “quiet; tranquil 平静” \\
\hline & $\mathrm{p} \tilde{\varepsilon} 22$ & colloquial & pẽ33.te33 “flat ground 平地” \\
\hline & $\mathrm{p}^{\mathrm{h} \tilde{\varepsilon} 35}$ & colloquial & 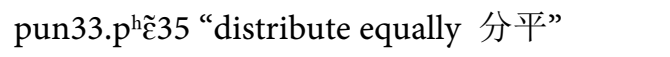 \\
\hline & $\mathrm{p}^{\mathrm{h}} \tilde{\varepsilon} 22$ & colloquial & $\mathrm{p}^{\mathrm{h}} \tilde{\varepsilon} 33$.pun51 “revenue equals cost 平本” \\
\hline \multirow[t]{5}{*}{ 落 } & dek41 & literary & dek65.ke41 “reduce price 落价” \\
\hline & dok221 & literary & dðk32.sit221 “put into effect 落实” \\
\hline & $d_{\theta} 22$ & colloquial & de32.ћ๊33 “to rain 落雨” \\
\hline & dew41 & colloquial & dew63.thew33.tsen35 “hair loss 落头发” \\
\hline & dew22 & colloquial & ke33.dew22 “fall away 落掉” \\
\hline \multirow[t]{5}{*}{ 相 } & sjen35 & literary & ћo32.sjen35 “mutually; each other 互相” \\
\hline & $\operatorname{sjen} 41$ & literary & tsrj35.sjen41 “prime minister 宰相” \\
\hline & sje35 & colloquial & sje33.tsjew63.ko41 “look after mutually 相照顾” \\
\hline & sjõ35 & colloquial & sjõ33.si35 “mutually lovesick 相思” \\
\hline & sjõ41 & colloquial & 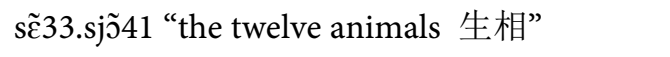 \\
\hline \multirow[t]{5}{*}{ 长 } & $\operatorname{tjen} 22$ & literary & tjen33.sju33 “long life; longevity 长寿” \\
\hline & tjen51 & literary & tjen35.pwe41 “elder member of a family 长辈” \\
\hline & $\operatorname{tn} 22$ & colloquial & tn33.te51 “long and short 长短” \\
\hline & tjõ51 & colloquial & kع33.tjõ51 “the head of a family 家长” \\
\hline & tjõ22 & colloquial & tje33.thwe41 “Changtai (place) 长泰” \\
\hline
\end{tabular}

\section{Conclusion}

This study provides an illustration of how the heteronym system is constructed and how different pronunciation forms are related in the Southern Min variety of Zhangzhou. The descriptions show that the Zhangzhou heteronyms can be classified into different categories at different layers in accordance to various criteria including the distinction of grammatical categories and lexical meanings; the usage of a colloquial or literary style; the usage of a general or specific style, the correspondence between the literary and colloquial forms in terms of syllable onset, final and tone, as well as the number of pronunciations that polyphonetic characters have.

Additionally, some patterns can also be found with respect to the relationship between different pronunciation forms across diphonetic, triphonetic, quadriphonetic, and quintophonetic characters. The results suggest that although the heteronyms are substantially abundant in Zhangzhou, they are essentially arranged in a systematic and generalisable way. This not only reflects a dynamic linguistic phenomenon in this Sinitic dialect, but also indicates the heterogeneous nature of human languages. This study expands our understanding of the arrangement of heteronyms in the Southern Min variety of Zhangzhou, and also serves as a model to investigate how heteronyms are constructed and categorised in other Sinitic languages/dialects and beyond. It also sheds light on future stu- 
dies with respect to how language and culture are interacted in this Southern Min variety.

\section{Conflicts of Interest}

The author declares no conflicts of interest regarding the publication of this paper.

\section{References}

Bergeron, D. (1990). Heteronyms. English Today, 6, 39-44. https://doi.org/10.1017/S0266078400005150

Chao, Y. (1930). A System of “Tone Letters”. Le Maître Phonétique, 45, 24-27.

Cramer, P. (1970). A Study of Homographs. In L. Postman, \& G. Keppel (Eds.), Norms of Word Association (pp. 361-382). New York: Academic Press. https://doi.org/10.1016/B978-0-12-563050-4.50011-X

Huang, Y. (2018). Tones in Zhangzhou: Pitch and Beyond. PhD Dissertation, Canberra: Australian National University. https://openresearch-repository.anu.edu.au/handle/1885/144938

Huang, Y. (2019). Zhangzhou Southern Min: Rhyme Tables, Homonyms, Heteronyms, Vernacular Documentation. München: Lincom Europa.

Liu, W., \& Guthrie, L. (2009). Chinese Pinyin-Text Conversion on Segmented Text. In V. Matoušek, \& P. Mautner (Eds.), TSD 2009: Text, Speech and Dialogue (pp. 116-123). Lecture Notes in Computer Science, Vol. 5729, Berlin, Heidelberg: Springer. https://doi.org/10.1007/978-3-642-04208-9 19

Ma, C. (1994). Studies of Zhangzhou Dialect. Hong Kong: Zongheng Chubanshe.

Martin, M., Jones, G. V., Nelson, D. L., \& Nelson, L. (1981). Heteronyms and Polyphones: Categories of Words with Multiple Phonemic Representations. Behavior Research Methods \& Instrumentation, 13, 299-307. https://doi.org/10.3758/BF03202018

Rothwell, D. (2007). The Wordsworth Dictionary of Homonyms. Hertfordshire: Wordsworth Editions.

Sung, M. M. (1973). A Study of Literary and Colloquial Amoy Chinese. Journal of Chinese Linguistics, 1, 414-436.

Zhang, J., \& Yang, J. (2009). An Introduction to Traditional Chinese Phonology. Shanghai: Fudan University Press. 